\title{
Invasive Carcinoma Mammae dengan Metastasis Orbita, Tulang dan Paru
}

Putri Avryna ${ }^{1}$, Irza Wahid², Fauzar ${ }^{3}$

\begin{abstract}
Abstrak
Carcinoma mammae (kanker payudara) merupakan penyakit keganasan yang paling banyak terjadi pada wanita di negara berkembang dan merupakan penyebab kematian wanita kedua di Amerika Serikat. Pada tahun 2014 terdapat 232.000 kasus baru pada wanita di Amerika Serikat dan dengan angka kematian 40.000 jiwa. Invasive breast carcinoma paling banyak berasal dari epitel duktus dan lebih dari $75 \%$ merupakan invasive ductal carcinoma not otherwise specified (IDC-NOS). Angka kejadian metastasis orbita 2-9\% dari semua kasus keganasan pada dewasa dan $8-10 \%$ berasal dari kanker payudara. Pada kasus ini, wanita 36 tahun datang dengan keluhan sesak napas dan terdapat benjolan pada mata kiri sejak 2 bulan yang lalu. Pasien telah dikenal menderita Ca Mammae dengan hasil biopsy jaringan ditemukan Invasive Carcinoma Mammae Of No Special Type (NST) Grade /I sejak 1,5 tahun sebelumnya, namun menolak pengobatan dan kemoterapi. Saat ini telah terjadi metastasis di orbita, metastasis tulang dan paru. Pasien diberikan kemoterapi dengan regimen Carboplatin (AUC 6) dan Paclitaxel $170 \mathrm{mg} / \mathrm{m}^{2} \mathrm{dan}$ mengalami perbaikan secara signifikan.
\end{abstract}

Kata Kunci: kanker payudara, metastasis multipel, metastasis orbita, metastasis tulang, metastasis paru

\section{Abstract}

Carcinoma mammae is the most common malignancy in women in developing countries and is the second leading cause of death of women in the United States. In 2014, there were 232,000 new cases of women in the United States and with a death toll of 40,000. Invasive breast carcinoma is mostly from ductal epithelium and more than $75 \%$ is invasive ductal carcinoma not otherwise specified (IDC-NOS). The incidence of orbital metastases is $2-9 \%$ of all malignant cases in adults and 8-10\% are from breast cancer. In this case, a 36-year-old woman came with a complaint of shortness of breath and a lump in the left eye since 2 months ago. The patient has been known to suffer from Mammary Ca with tissue biopsy results found in invasive carcinoma mammary of no special type (NST) Grade II since 1.5 years before, but refused treatment and chemotherapy. At present there has been metastasis in the orbit, bone and lung metastases. Patients were given chemotherapy with the regimen of Carboplatin (AUC 6) and Paclitaxel 175 $\mathrm{mg} / \mathrm{m}^{2}$ and experienced significant improvement.

Keywords: carcinoma mammae, multiple metastasis, ophtalmic metastasis, bone metastasis, lung metastasis

Affiliasi penulis: 1. Program Pendidikan Dokter Spesialis-1 IImu Penyakit Dalam FK Unand, 2. Subbagian Hematologi dan Onkologi Medis Bagian IImu Penyakit Dalam FK Unand/RSUP M Djamil Padang 3, Subbagian Paru Bagian IImu Penyakit Dalam FK Unand/RSUP M Djamil Padang

Korespondensi: pibipd@yahoo.comTelp: 0751-37771

\section{PENDAHULUAN}

Carcinoma Mammae (kanker payudara) merupakan penyakit keganasan yang paling banyak terjadi pada wanita di negara berkembang dan merupakan penyebab kematian wanita kedua di Amerika Serikat. ${ }^{1}$ Pada tahun 2014 terdapat 232.000 kasus baru kanker payudara pada wanita di Amerika Serikat dan angka kematian sebanyak 40.000 kasus. Invasive breast cancer merupakan kanker payudara yang bervariasi dari segi tampilan, klasifikasi berdasarkan patologi dan gejala klinis. Kebanyakan sel tumor berasal dari epitel duktus terutama the 
terminal duct-lobular unit dan lebih dari $75 \%$ merupakan invasive ductal carcinoma not otherwise specified (IDC-NOS). 1,2

Lokasi paling sering terjadinya metastasis pada kanker payudara yaitu paru dan pleura (15-20\%), tulang $(20-60 \%)$, hati $(5-15 \%)$, otak ( $5-10 \%)$ dan metastasis lokal/regional $(20-40 \% \%){ }^{3}$ Selain lima lokasi yang disebutkan sebelumnya, kanker payudara juga dapat bermetastasis ke orbita. Angka kejadian metastasis orbita $2-9 \%$ dari semua kasus keganasan pada dewasa dan $8-10 \%$ berasal dari kanker payudara. Tumor primer biasanya terdiagnosis sebelum terdapat gejala metastasis ke orbita. Mean survival time pasien dengan kanker payudara adalah sekitar 22-31 bulan setelah metastasis ke orbita. 3,4

Terapi pada pasien dengan kanker payudara yang telah bermetastasis bersifat individual dan not curable. Untuk itu tujuan utama dalam terapi adalah meningkatkan kualitas hidup, meringankan gejala yang terjadi akibat suatu metastasis. Kemoterapi merupakan pilihan terapi pada kanker payudara dengan metastasis yang progresif dan beresiko mengenai organ-organ penting. Kemoterapi juga digunakan pada kanker payudara dengan status hormon reseptor yang negatif dan pada pasien yang telah mendapat terapi antihormonal namun tidak memiliki respon yang baik. ${ }^{5}$

\section{KASUS}

Seorang wanita umur 36 tahun datang dengan keluhan sesak napas yang semakin meningkat sejak satu hari sebelum masuk rumah sakit. Sesak napas telah dirasakan pasien sejak 3 minggu sebelumnya. Pasien mengeluhkan tidak dapat tidur terlentang dan lebih nyaman bila tidur dalam posisi setengah duduk. Pasien juga mengeluhkan mata kiri yang tampak semakin menonjol sejak 2 bulan yang lalu. Awalnya pasien sering mengalami sakit kepala disebelah kiri, sakit dirasakan menusuk-nusuk dan hilang timbul, kemudian keluhan ini disertai dengan pandangan yang semakin kabur.

Pasien didiagnosis menderita kanker payudara sejak satu setengah tahun yang lalu. Awalnya pasien menemukan benjolan di payudara kanan sebesar kelereng sekitar $3 \mathrm{~cm}$ diatas puting susu. Benjolan tersebut semakin membesar dalam waktu enam bulan sampai sebesar telur ayam. Kemudian benjolan dioperasi namun tidak dilakukan pemeriksaan jaringan. empat bulan sebelum masuk rumah sakit, benjolan kembali dirasakan pasien namun kali ini berjumlah 3 buah sewarna kulit, teraba keras dan tidak dapat digerakkan. Dilakukan pengangkatan payudara kanan dan dilakukan pemeriksaan patologi dengan hasil invasive carcinoma mammae of no special type (NST) Grade II. Saat itu pasien disarankan untuk segera memulai kemoterapi namun pasien menolak. Faktor resiko kanker payudara pada pasien ini terlihat dari riwayat merokok sejak umur 16 tahun, banyaknya \pm 1 bungkus per dua hari. Pasien berhenti merokok sejak 1 tahun yang lalu.terdapat pula riwayat minum alkohol selama lebih kurang tiga tahun dan riwayat menggunakan alat kontrasepsi hormonal.

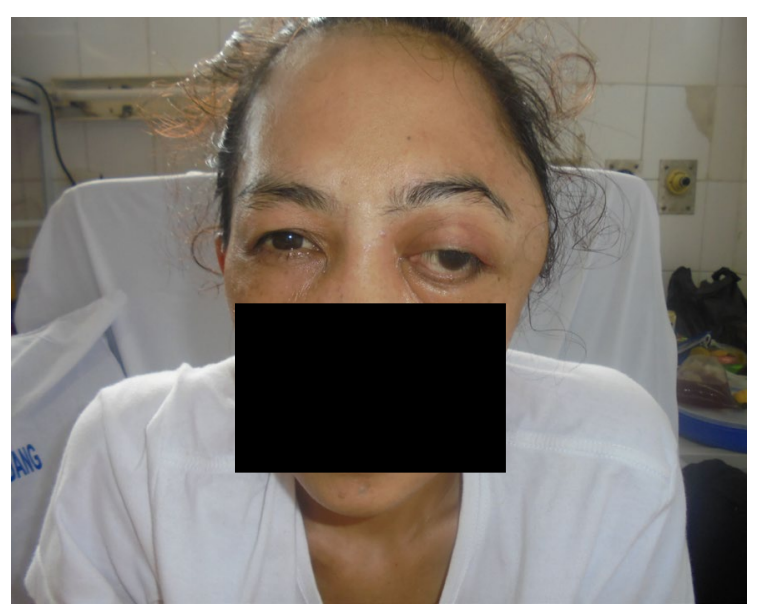

Gambar 1. Proptosis pada mata kiri pasien sebelum dilakukan kemoterapi

Pemeriksaan fisik awal didapatkan keadaan pasien yang tampak sakit sedang, dengan kesadaran compos mentis, tekanan darah $120 / 70 \mathrm{mmHg}$, nadi 110kali/menit, napas $30 \mathrm{kali} / \mathrm{menit}$ dan suhu 37 derajat Celsius. Mata kiri terlihat lebih menonjol dibandingkan mata kanan. Terdapat tattoo pada punggung dan kedua lengan pasien. Pada pemeriksaan paru didapatkan suara napas yang menurun di basal paru kanan setinggi RIC IV kebawah dan setinggi RIC II kebawah di sebelah kiri yang menggambarkan suatu efusi pleura bilateral. Pasien didiagnosis sebagai Carcinoma mammae dekstra post radikal mastektomi dengan metastasis ke orbita sinistra dan suspek metastasis paru. 
Dilakukan CT scan kepala dan didapatkan hasil lesi destruksi pada sphenoid bone kiri dengan perluasan ke retrobulber/ ekstra konal dengan protusio bulbi sinistra, perluasan ke sinus maksilaris kiri, M. pterigoid lateral kiri, M.temporal kiri serta intrakranial pada gyrus temporal inferior kiri. Destruksi os temporal, dinding lateral orbital, dan maksilaris kiri. Dari pemeriksaan visus didapatkan visus pada mata kanan dalam batas normal, namun visus mata kiri 0 , terdapat protusio dan keterbatasan gerak bola mata kesegala arah, namun biopsi pada mata kiri tidak dilakukan.

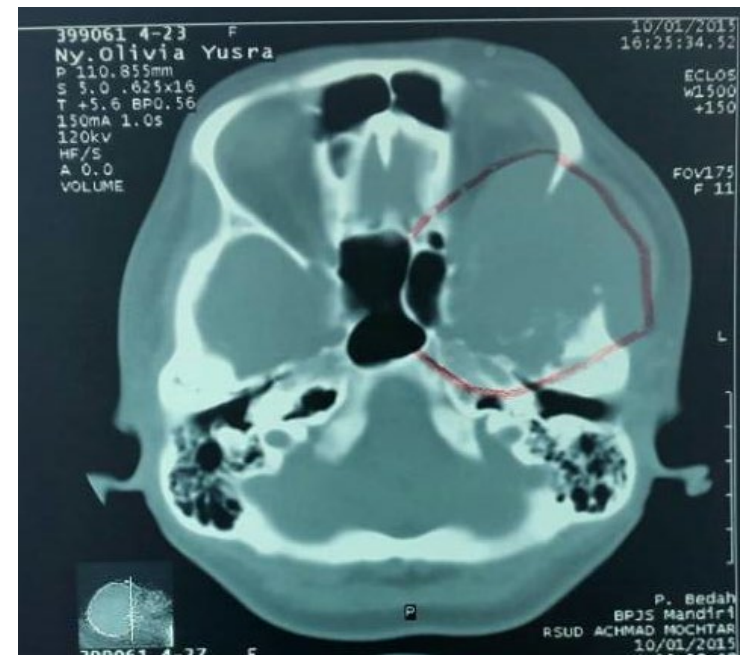

Gambar 2. CT Scan kepala memperlihatkan massa yang mendestruksi os temperoral, dinding lateral orbital dan maxilaris kiri

Tatalaksana efusi pleura pada pasien ini ialah dengan dilakukan torakosintesis dan dilakukan analisa cairan pleura dengan warna kuning kemerahan dan kesan eksudat. Setelah dilakukan torakosintesis sebanyak $\pm 1500 \mathrm{cc}$ dalam dua kali pengambilan, dilakukan foto thorak ulang dan didapatkan nodul pada hemithorax kiri yang diduga merupakan suatu lesi metastasis. Dari pemeriksaan sitologi cairan pleura didapatkan kesan suatu radang. Dilakukan staging pada pasien ini dengan melakukan USG abdomen, echocardiografi dan bone survey.

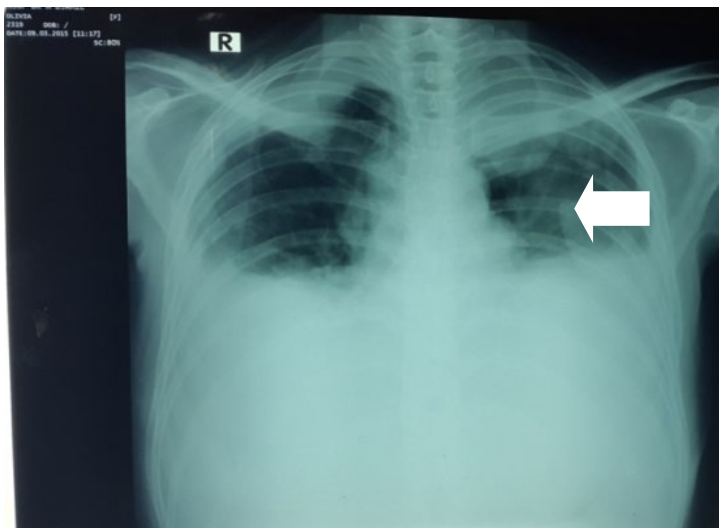

Gambar 3. Rontgen thorak setelah dilakukan pleurosintesis pada pleura kiri. Tampak nodul pada paru kiri yang dicurigai suatu lesi metastase

Hasil USG abdomen tidak didapatkan lesi metastasis di hepar, namun dari hasil bone survey didapatkan lesi litik pada os fronto parietal. Hasil echocardiography didapatkan Ejection Fraction 65\%. Sehingga pasien didiagnosis sebagai Carcinoma mammae dekstra dengan metastasis orbita sinistra, bone metastasis di fronto parietal, dan suspek metastasis pleura dan paru kiri, T4N0M1 (Stadium IV) Indeks Karnofsky 80.

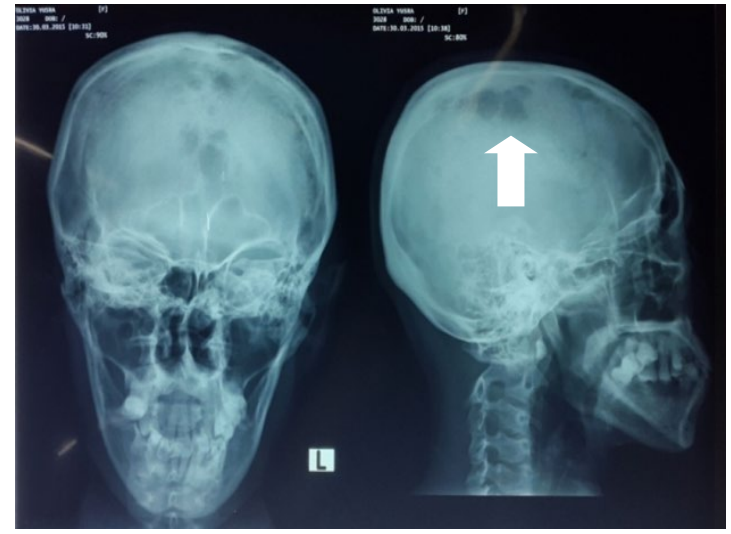

Gambar 4. Bone Survey menunjukkan terdapat lesilitik pada os frontoparietal

Pada pasien dilakukan kemoterapi pertama dengan regimen Carboplatin (AUC 6) dan Paclitaxel $170 \mathrm{mg} / \mathrm{m}^{2}$. Kemoterapi pertama didapatkan hasil yang cukup memuaskan dimana proptosis mata kiri berkurang secara signifikan dan visus mulai membaik. 
Berdasarkan pemeriksaan imunohistokimia berupa ER/PR dan HER2 didapatkan hasil ER: Positif kuat pada $50-80 \%$ sel tumor. PR: Positif kuat pada 50-80 \% sel tumor dan Her2/Neu: Negatif, maka direncanakan pemberian terapi hormonal setelah dilakukan 6 kali kemoterapi.

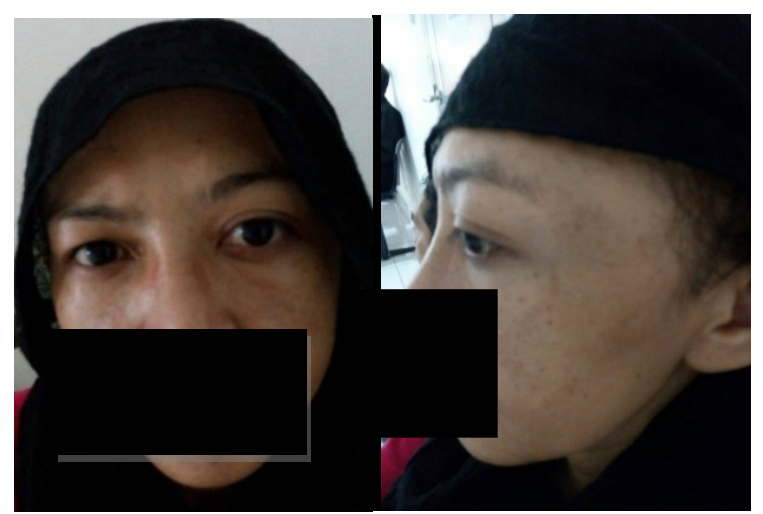

Gambar 5. Proptosis mata kiri berkurang secara signifikan setelah pemberian kemoterapi pertama dengan regimen Carboplatin dan Paclitaxel

\section{PEMBAHASAN}

Prevalensi metastasis ke orbita pada kanker payudara bervariasi antara $10 \%-37 \%$ pasien. Insiden metastasis kanker payudara ke orbita sulit dipastikan karena biasanya ditutupi oleh gejala metastasis kanker payudara ke organ lain. Tumor primer biasanya didiagnosis sebelum terdapat gejala metastasis ke orbita, dan rata-rata antara diagnosis tumor primer dengan metastasis ke orbita bervariasi 4,5-6,5 tahun. ${ }^{3}$

Kasus ini merupakan kasus kanker payudara yang telah bermetastasis jauh ke orbita sinistra, tulang frontoparietal dan paru. Pasien sudah dilakukan mastektomi radikal pada payudara kanan dan dilanjutkan dengan kemoterapi. Kanker payudara dengan metastasis bersifat not curable, maka target terapi pada pasien ini adalah perbaikan kualitas hidup dan mengurangi gejala yang ditimbulkan dari metastasis itu sendiri. ${ }^{5}$

Kemoterapi pada pasien ini diberikan dengan indikasi telah terjadinya metastasis jauh ke organ lain sehingga terapi sistemik menjadi pilihan. Kemoterapi yang diberikan dapat berupa obat tunggal atau berupa gabungan beberapa kombinasi pengobatan dan diberikan secara bertahap dalam 4-8 siklus. ${ }^{3,5}$ Pada pasien ini diberikan kemoterapi golongan Platinum agent Carboplatin (AUC 6) dan Paclitaxel 170 mg/m² dengan interval 21 hari sebanyak 6 siklus. Dari kemoterapi pertama telah menunjukkan hasil yang cukup baik dimana keluhan sesak dan mata kiri yang terlihat menonjol sudah berkurang. .,6 $^{-6}$

Hasil pemeriksaan imunohistokimia (IHK) didapatkan hasil yang positif pada ER/PR dan negatif pada HER-2. Pilihan utama terapi pada reseptor hormonal yang positif adalah pemberian terapi antihormonal. Namun pada pasien ini, metastasis yang terjadi luas dan melibatkan organ-organ penting sehingga kemoterapi dipilih sebagai terapi adjuvant. ${ }^{6}$

Penatalaksanaan metastasis ke tulang pada pasien ini adalah pemberian bisfosfonat Pemberian bisfosfonat berfungsi menghambat perluasan metastasis dan kerusakan tulang. Bisfosfonat dapat diberikan intravena maupun pemberian oral. Tergantung dari luasnya lesi tulang yang ditemukan. ${ }^{7}$

\section{SIMPULAN}

Pada kasus dengan metastasis dan stadium lanjut, kemoterapi konvensional merupakan pilihan terbaik untuk menghambat meluasnya kejadian metastasis tersebut. Status hormonal dan imunohistokimia menjadi acuan dalam pemberian terapi anti hormonal sebagai lanjutan dari pemberian kemoterapi.

\section{DAFTAR PUSTAKA}

1. United States Cancer Statistics Working Group: Department of Health and Human Services, Centers for Disease Control and Prevention, and National Cancer Institute; 2014. Tersedia dari: http://gis.cdc.gov/cancer/USCS/DataViz

2. Winstanley J, Murray M. Advanced breast cancer (update) diagnosis and treatment. NICE National Institute for Health and Care Excellence. 2014;1122.

3. Georgalas I, Paraskevopoulos, Koutsandrea C, Kardara E, Melamos P, Ladas D, et al. Ophtalmic metastasis of breast cancer and ocular side effects from breast cancer treatment and management: Mini Review. Biomed Res Int. 2015:1-8.

4. Gerber B, Freund M, Reimer T. Recurrent breast cancer treatment strategies for maintaining and prolonging good quality of life. dtsch arztebl int. 2010;107:85-91. 
5. Partidge $\mathrm{AH}$, Rumble RB, Carey LA, Come SE, Davidson NE, Leo AD, et al. Chemotherapy and targeted therapy for women with human epidermal growth factor receptor2-negative (or unknown) advanced breast cancer: American society of clinical oncology clinical practice guideline. J Clin Oncol. 2014;32:3307-9.
6. Burstein HJ, Ternin S, Anderson H, Buchloz TA, Davidson NE, Gelmon KE, et al. Adjuvant endocrine therapy for women with hormone receptor-positive breast cancer: American Society of Clinical Oncology Clinical Practice Guideline Focused Update. J Clin Oncol. 2014;20:2255-69.

7. Ingo JD. Bisphosponates in breast cancer patients with bone metastases. Breastcare. 2010;5:306-11. 